\title{
Interpreting the Stratigraphic Record of Glacial Readvances Along the Hudson River at Manhattanville, New York City, NY
}

\author{
Cheryl J. Moss, Mueser Rutledge Consulting Engineers, 14 Penn Plaza, New York, NY \\ 10122 (cmoss@mrce.com)
}

\section{Introduction}

New York City's bedrock is faulted and highly folded. Where the rock surface is fractured or softer (typically in the marble) it has generally been eroded into valleys, some quite deep. Glacial sediments, in some cases spanning multiple glaciations, commonly fill in these depressions and provide information about the different glacial advances over New York City.
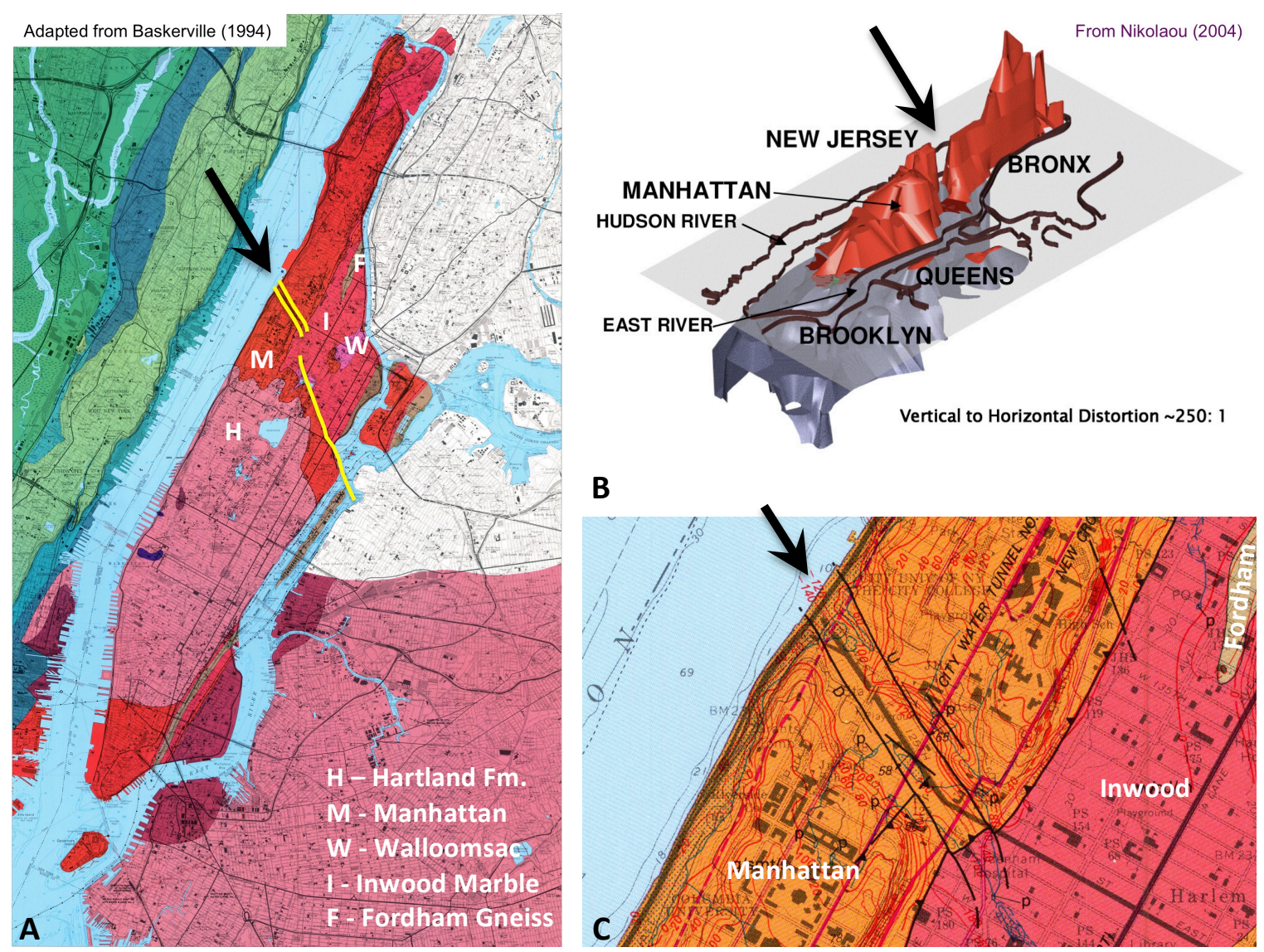

Figure 1 - (A) The bedrock geologic map of Manhattan (Baskerville 1994) with the $125^{\text {th }}$ Street Fault Zone highlighted in yellow. Map colors are hard to distinguish, but the Manhattan Fm. is orange-red and the Inwood Marble is pink-red. (B) 3D view showing top of rock. Rock above sea-level is colored red, below sea-level is blue. Deeper rock to the immediate east of the red ridge generally indicates the location of eroded Inwood Marble. The large gap below the arrow is where the $125^{\text {th }}$ Street Fault cuts across NYC. (C) $125^{\text {th }}$ Street Fault Zone where it cuts through the ridge of hard Manhattan Schist (colored orange on this map, Inwood Marble is red) on the engineering sheet of the geologic map. Red contour lines show top of rock elevations. Blue lines show former streams and ponds that are now filled in. 
There are numerous brittle faults scattered across New York City, but most are small with only a few having a pronounced mappable offset (Baskerville 1994). The most extensive and best known fault in the city is the $125^{\text {th }}$ Street Fault (Figure 1). In Manhattan it is a NW trending faulted zone that starts at the Hudson River and $125^{\text {th }}$ Street. Heading SE it cuts through a $\sim 120$ ' high ridge of hard Manhattan Schist that is present along the eastern shore of the Hudson River, before it turns to the SSE and crosses upper Manhattan and extends a short distance into Queens. Several hundred borings from numerous projects, old (MRCE archives) and especially new (Columbia University Manhattanville Development), indicate that between Broadway and the Hudson River the fault was eroded into a 300' deep, irregular, tiered valley that filled with numerous different strata that recorded the advance and retreat of glacial ice across the Manhattanville neighborhood (Figure 2).

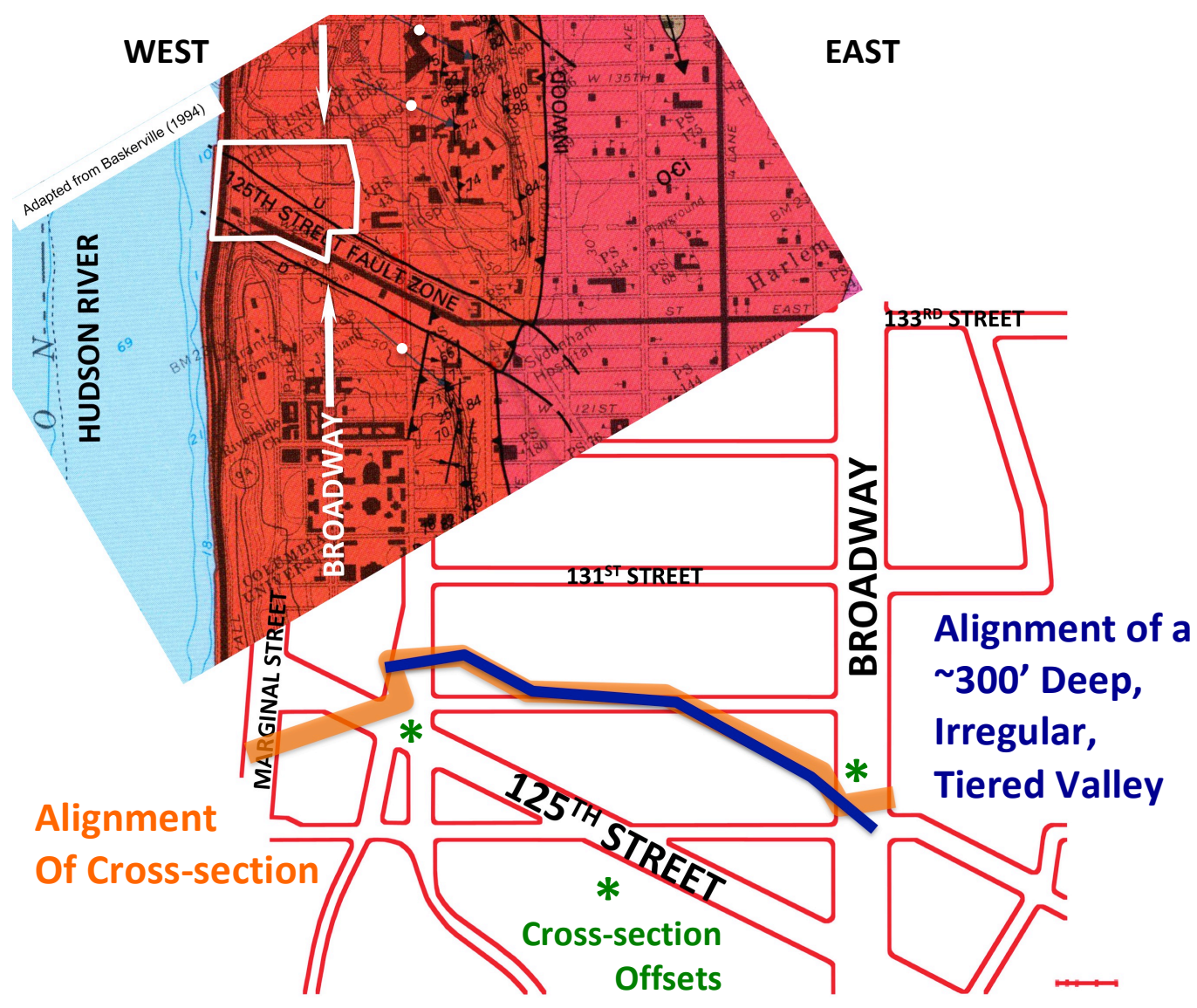

Figure 2 - Portion of the Manhattan geologic map with the study area outlined in white. The 3 white dots are centered over long, thin blue arrows that mark the orientation of glacial striations mapped at the tip of the arrows on the bedrock ridge above the valley. Striations indicate that the last major ice flow followed the trend of the valley. The street map identifies the study area. The dark blue line traces the alignment of the deepest part of a roughly 300' deep, irregular, tiered valley present in the fault zone between Broadway and the Hudson River. The orange line is the alignment of the geologic cross section shown in later figures. Note that there are 2 offsets in the section - at the western end the section runs down the valley side, then shifts north to cross the valley directly, then turns eastward to cross the western outlet and run down along the center of the valley, before turning again to run up the steep rock slope at the eastern end of the valley just before reaching the eastern outlet. 


\section{Age of Strata}

There is no available information that will place an exact date on the sediments present in this valley, so some assumptions must be made to determine an approximate age for the strata. A lot of different factors affect how the bedrock weathers, but in New York City there are a few common trends. The calcareous Inwood Marble is very prone to weathering, which makes the already comparatively soft rock more susceptible to erosion. New York City bedrock valleys that don't follow faults often follow scoured out marble (Figures $1 \& 10$ ).

In comparison, the harder schists and gneisses (Fordham Gneiss, Manhattan Fm. and Hartland Fm.) are more weather resistant and are usually the formations that form ridges and outcrops. Surface rock that was scoured down to fresh rock more recently during the Wisconsinan glaciation tends to be unweathered to slightly weathered and the weathered zones, where present, tend to be fairly thin. There is generally little to no saprolite. The weathering pattern is often different, however, when these rocks are below Cretaceous soils or known older glacial (Illinoian Jameco Gravel) and inter-glacial (Sangamon Gardiners Clay) strata. These areas of bedrock that have been shielded from more recent glacial erosion by the overlying soil, tend to have fairly thick zones where the older rock surface has had the time to become moderately to highly weathered, in some places even decomposed to thick layers of saprolite (Figure 3).

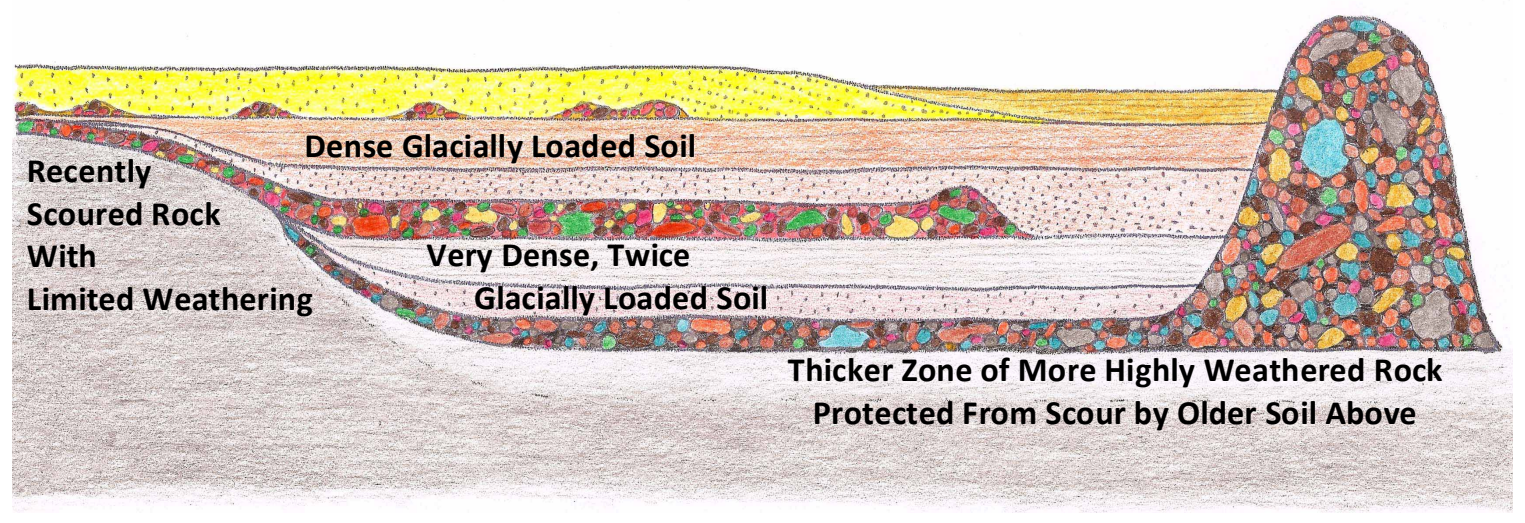

Figure 3 - Schematic drawing of a common glacial sequence found in NYC, particularly in bedrock valleys. Bedrock is scoured down to fresh rock during a glacial advance, and assorted glacial sediments are left behind after its retreat. At some later date, a glacial readvance scours down the near surface rock again, before it flows over the older soil that shields the deeper rock below. This soil is densified by the weight of the ice above and allows the underlying rock to continue weathering undisturbed. (Image adapted from Moss 2011b).

Where the valley is carved into the Manhattan Schist below Manhattanville, the bedrock surface often has only a thin layer of weathered rock and little saprolite. This suggests that the overlying sediments are more recent, rather than from an older glaciation that would have protected the rock below from later glacial scour. If this assumption is correct, then the valley was formed from stream and/or glacial erosion prior to and during the main advance of the Wisconsinan ice. 


\section{First Glacial Advance}

The deepest crevices and the lowest tier of the valley were filled with a very dense till composed primarily of boulders, cobbles and gravel with sand, silt and clay matrix, which is presumably the Wisconsinan basal till (Figure 4). During a retreat of the ice this till was covered over with a layer of gray, brown and red brown varved silt and clay with some interlayers of brown to red brown silty to clean fine sand. This glacial sequence of till and stratified drift reaches up to the level of the valley's eastern and western outlets at roughly elevation $-160^{\prime}$. Since the varved silt and clay is contained within the bottom tier of the valley below the level of the outlets, it may have been deposited locally, separate from any larger glacial lake that might have been present at the time in the Hudson or to the east in the Harlem and East Rivers.

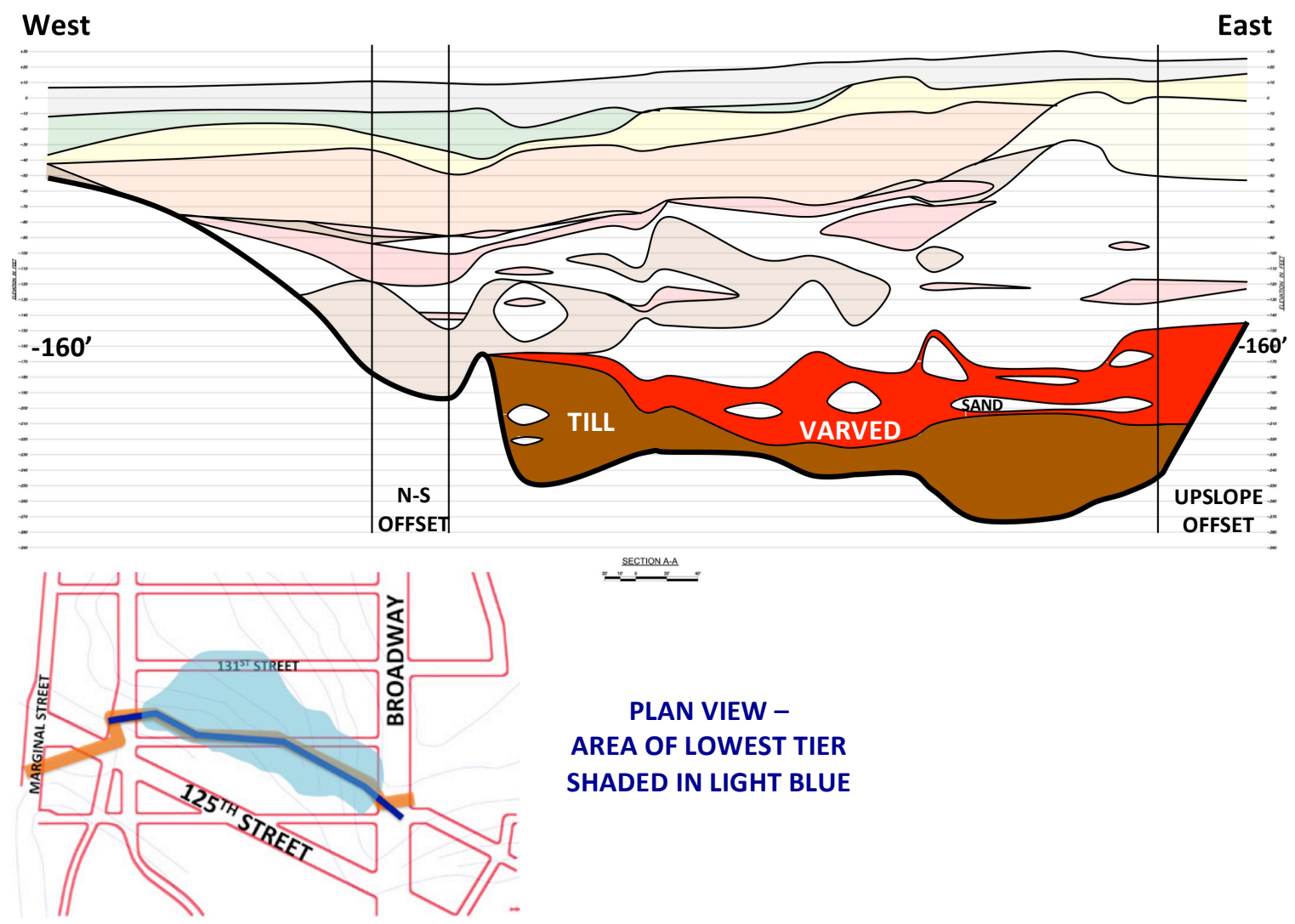

Figure 4 - Geologic cross-section along the valley featuring strata from the first glacial advance. Strata from the first advance that fills the lowest tier of the valley is in dark shading. The dense bouldery and cobbly till at the bottom is probably the Wisconsinan Last Glacial Maximum basal till. It is covered with a layer of varved silt and clay with thin layers of fine grained outwash sand up to the level of the valley outlets at roughly elevation -160 '. In plan view, the area containing the lowest tier is shaded in light blue. For comparison, the thin blue lines are the top of rock contours traced from the geologic map engineering sheet shown in figure 1C. The valley is generally wider at the Hudson and narrows eastward at Broadway, but is much deeper than the map contours would suggest. 


\section{First Identified Glacial Readvance}

A readvance of the ice covered the older varved soil with outwash and deposited a layer of till over the bedrock west of the western outlet and across the outlet, and sent a lobe eastward partway into the valley (Figure 5). This till lens was surrounded and covered with outwash before a more extensive layer of till was deposited above. The till is a brown and gray fine to coarse sand, with gravel, many cobbles and boulders, and varying amounts of silt. It typically becomes more sandy towards the edges. These till layers are extensively interlayered with clean outwash sands and varved deposits. The amount of interlayering and stratified drift present indicates that a melting, fluctuating ice front sat over the neighborhood before further retreat of the ice covered the site with varved soil. Brown and light brown silt, clayey silt, silty clay and silty fine sand was initially deposited at the eastern end of the valley at the level of, and likely originating from, the earlier till lobe. Later these glacial lake sediments proceeded to fill in the southern side of the valley from the southwest, likely moving in from the Hudson, before spreading northward to cover the more recent till.

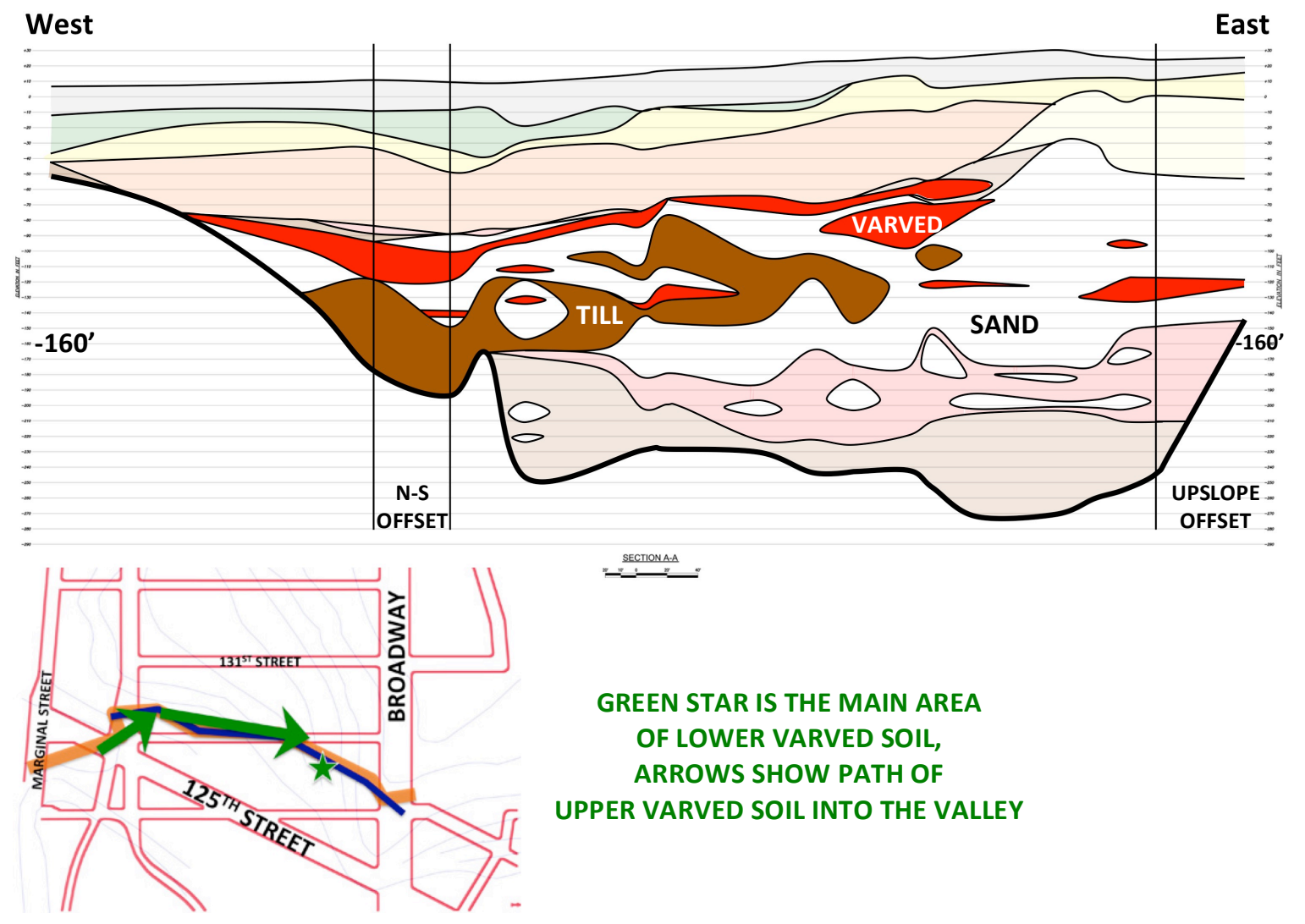

Figure 5 - Geologic cross-section along the valley featuring strata from the first glacial readvance. Strata from this readvance are shown in dark shading. Ice depositing till first entered the valley through the western outlet, before it then fluctuated across the site. Till, outwash sand and varved deposits are highly interlayered and dominated by meltwater deposition. Early varved soil was deposited east of the initial till advance. When the ice receded the main varved stratum entered the valley from the southwest, likely from the Hudson. 


\section{Second Identified Glacial Readvance}

Another readvance of the ice planed off these deposits roughly level with the top of the bedrock along the north and south sides of the valley, and in most places covered them with another layer of till of greatly varying thickness (Figure 6). This material is typically a brown to gray fine to coarse sand, with gravel and varying amounts of silt or occasionally clay. Till is thick along portions of the valley's north and south sides and thin along most of its axis, forming a basin. The underlying outwash is very dense, indicating the entire valley was ice loaded even where only thin till is present above. As the ice retreated varved soil started filling in from the SW along the river, suggesting a direct connection to an unidentified glacial lake in the Hudson, before the varved soil proceeded to fill in the basin and then cover the site. This soil consists of brown and red brown clayey silt varved with red silt, and varying amounts of gray or red brown silty clay.

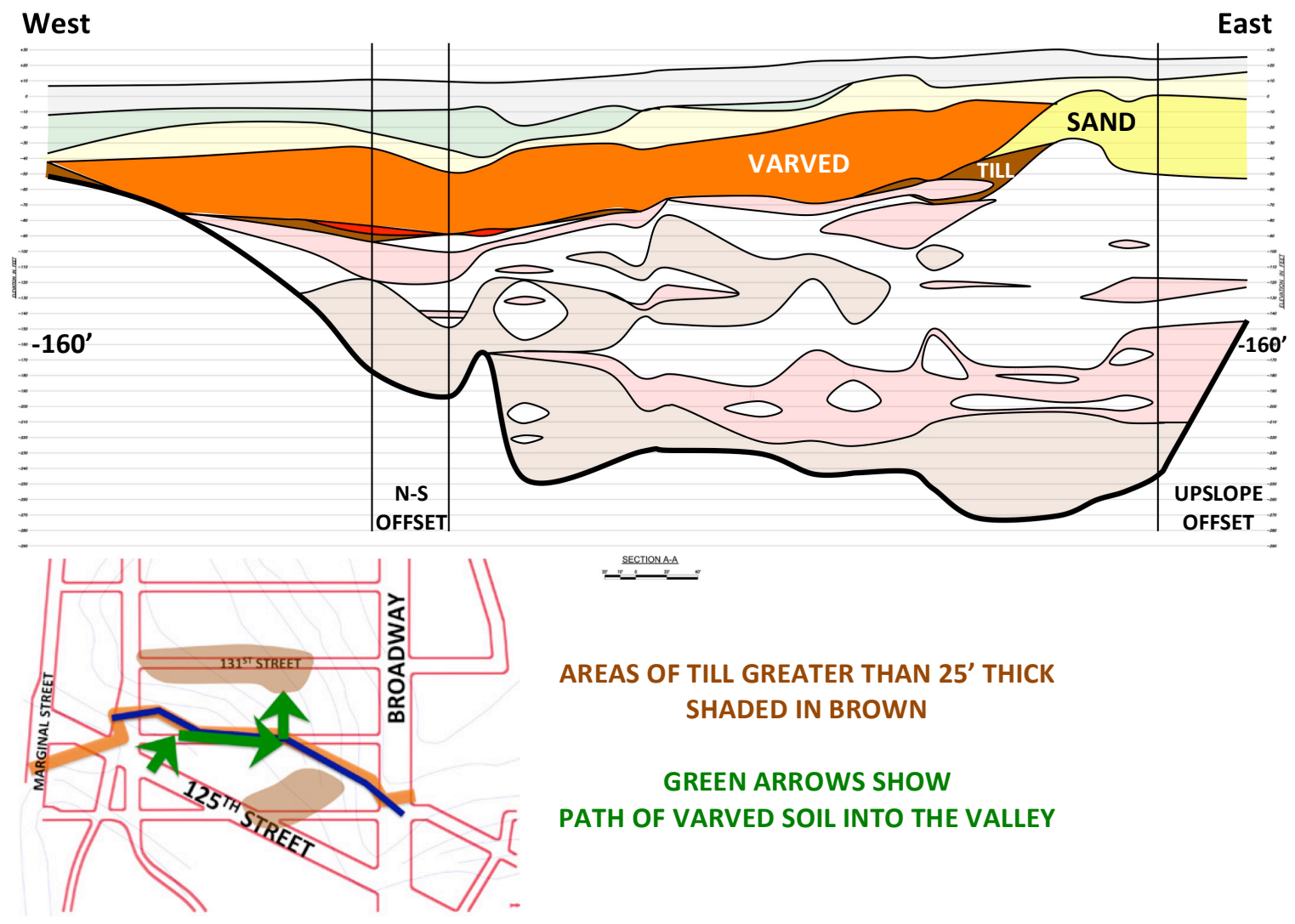

Figure 6 - Geologic cross-section along the valley featuring strata from the second glacial readvance. Strata from this readvance are shown in dark shading. During this readvance the ice planed off the previous sediments roughly level with the top of rock along the north and south sides of the valley and covered most of them with a layer of till. The till is very thin along the center of the valley, but has thick zones along its north and south sides forming a basin. Areas where the till is greater than $25^{\prime}$ thick are shaded brown on the plan view. When the ice retreated from the region varved sediments entered the valley from the southwest, probably from a glacial lake present in the Hudson, filled the basin, and then covered the site. 


\section{Drop in Groundwater Table}

The surface of this uppermost varved stratum is quite dense, typical of a desiccated profile (Moss \& Merguerian 2005). At some point the groundwater table dropped below the surface of the varved stratum. It is unclear what geologic event (or combination of events) prompted this to happen. If the varved stratum was deposited in glacial Lake Bayonne, then the opening of the outlet at Hell Gate would have dropped the site's groundwater close to the level of Lake Hudson (Stanford 2010b). If the stratum was deposited in Lake Hudson, which appears more likely based on the map, then the water level would have dropped with the lake level when the Narrows was breached (Figure 7). As the ice receded further to the north the region started to rise relative to sea-level due to post-glacial isostatic rebound. The Hudson River was able to cut down into the remaining glacial sediments filling the river valley, allowing the local groundwater table to drop accordingly.

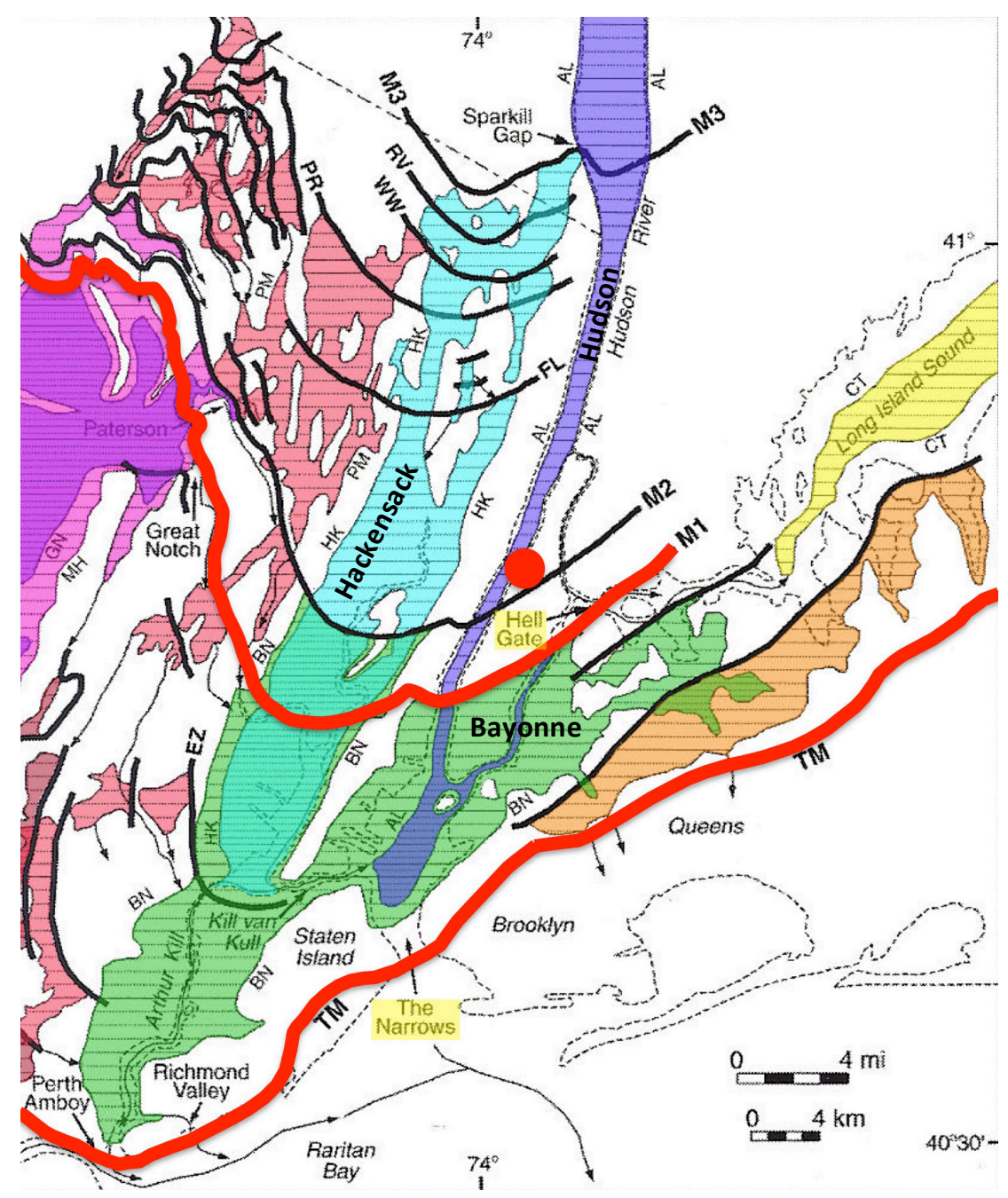

Figure 7 - Glacial lakes around New York City modified from Stanford (2010b). Glacial Lake Bayonne (green) dropped down to the level of Lake Hudson (dark blue) when ice retreated north of line M1 and an outlet to Long Island Sound opened up at Hell Gate. Lake Hudson drained to the Lake Albany level after the terminal moraine (TM) was breached at The Narrows. Manhattanville is located at the red dot. 


\section{Holocene and Recent Strata}

Much of the site is covered with interlayered gravel and sand (Figure 8). This stratum appears be a mix of depositional environments that span a considerable duration of time and may include more recent reworking of older deposits, particularly glacial till. In many locations, the material looks distinctly like glacial till or outwash. Given that it is generally the upper deposit in a valley, it is probably alluvial/colluvial sediment derived from the surrounding higher ground.

Where the ground surface is low-lying, mainly at the western end of the site, alluvial sand is mixed with organic silt and overlain by organic clay and peat deposits. Historic maps show former streams, ponds and embayments in these areas (Figure 1). Since the neighborhood has been developed the ground surface has been covered with a layer of miscellaneous fill.

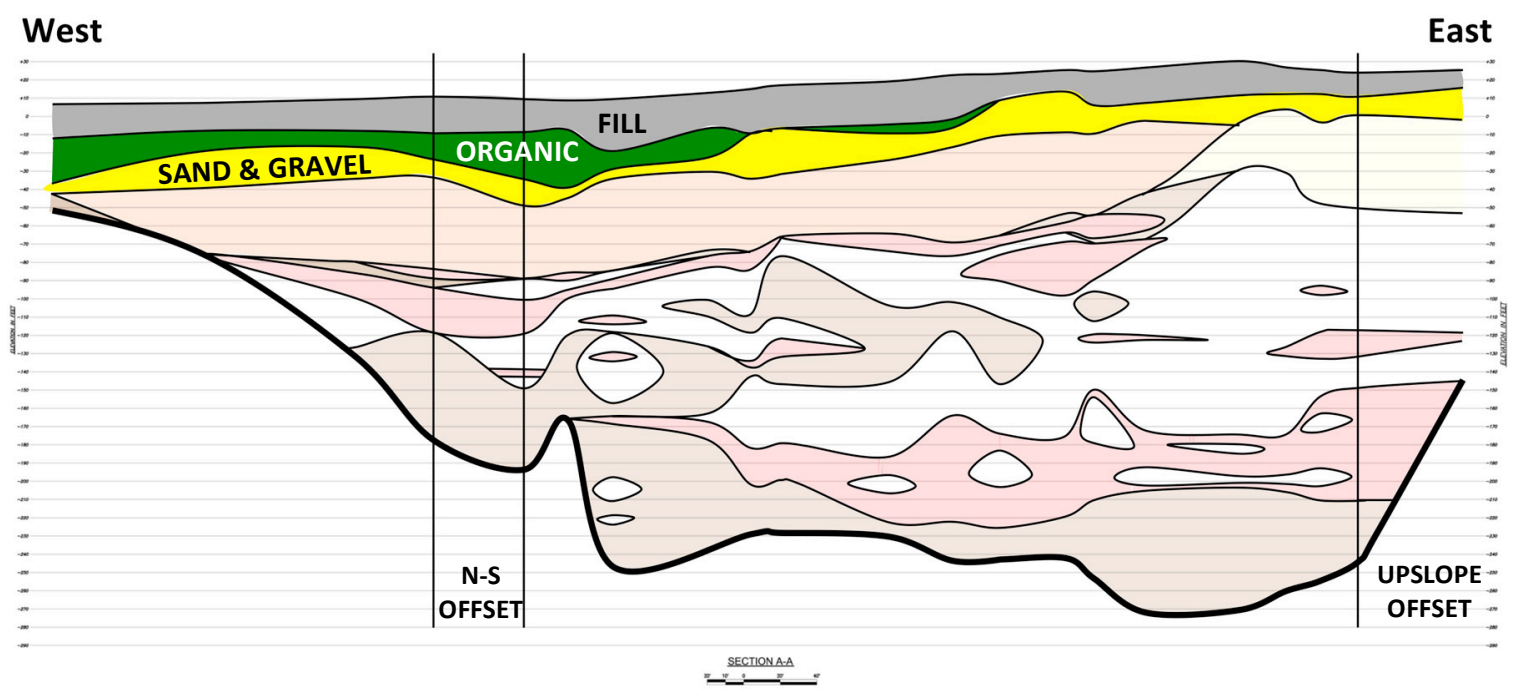

Figure 8 - Geologic cross-section along the valley featuring post-glacial strata. Additional strata, shown in dark shading, were deposited above the varved soil and outwash sand left behind after the final retreat of ice. The site is covered with a layer of sand and gravel that is probably reworked sediment derived from the surrounding higher ground. Streams, ponds and embayments filled low-lying portions of the site, allowing organic soil to be deposited. Since the neighborhood was developed the surface is covered with a layer of miscellaneous fill.

\section{Interpretation}

The Manhattan Schist is typically a hard, weather resistant rock, but fracturing in a fault zone increases its chance of weathering, making it more prone to erosion. The region has experienced at least 3 periods of glaciation - pre-Illinoian, Illinoian and advances during the Wisconsinan (Figure 9)(Stanford 2010b). Scour from pro-glacial streams and glacial ice was probably responsible for carving out most of the valley through the ridge of schist. Glacial striations mapped along the valley across the top of the ridge indicate that at least the Wisconsinan ice flowed from NW to SE, essentially parallel to the valley 
(Figure 2)(Baskerville 1994). The valley is wider on the west along the Hudson and narrows and deepens to the east at Broadway, suggesting that funneling the water/ice flow through the hard narrow eastern outlet may have contributed to scouring the broken and weathered rock down deeper on that outlet's western side. The effect may be similar to the plunge pools seen at the WTC site (Figure 10)(Moss \& Merguerian 2009).

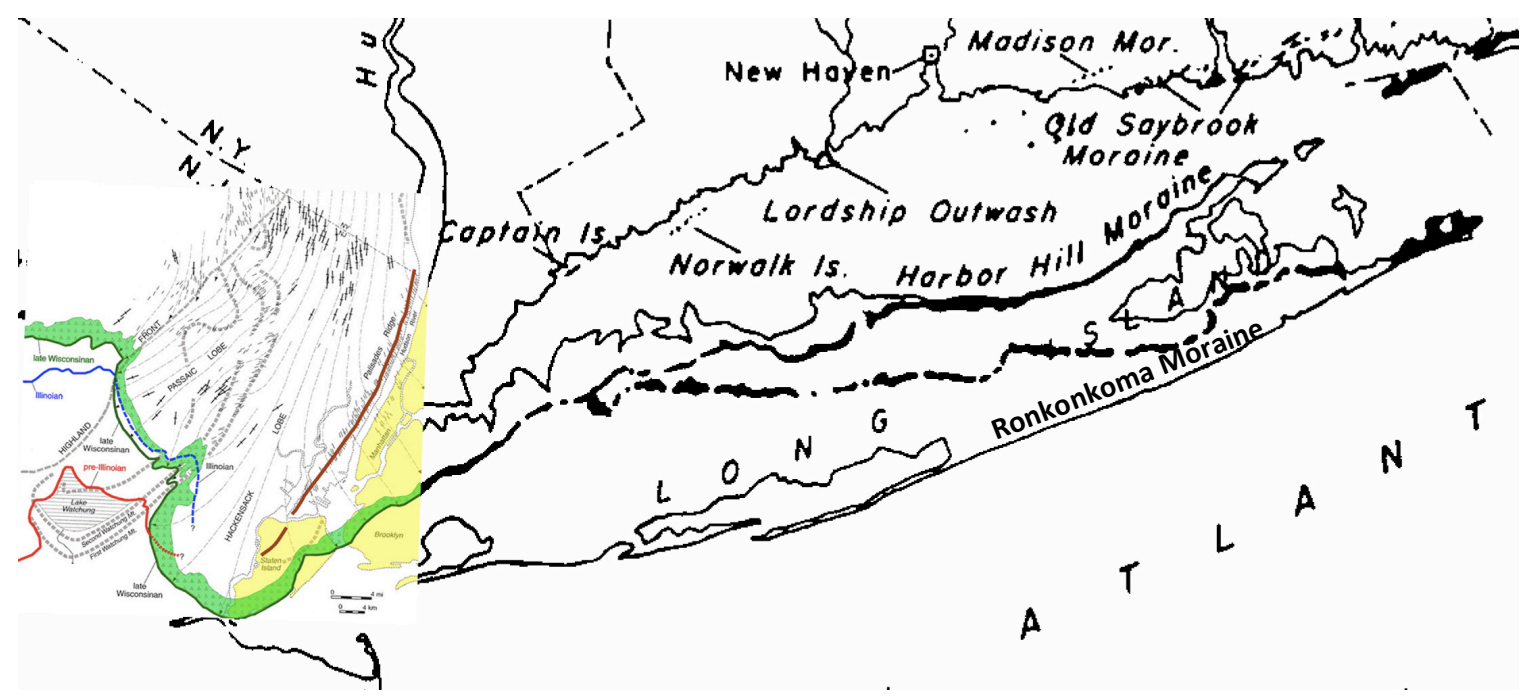

Figure 9 - Composite map that shows the extent of past glaciations in the New York City region. At the map's western edge in New Jersey the red line shows the extent of a pre-Illinoian advance. The blue line marks the Illinoian glaciation, and the green line shows the Wisconsinan Last Glacial Maximum. This extends eastward across NYC and northern Long Island as the Harbor Hill Moraine. The Ronkonkoma Moraine forms the south fork of Long Island and is generally considered to mark the extent of an earlier Wisconsinan advance. (Modified from Stanford (2010b) and Flint and Gebert (1974) in Moss 2013b.)
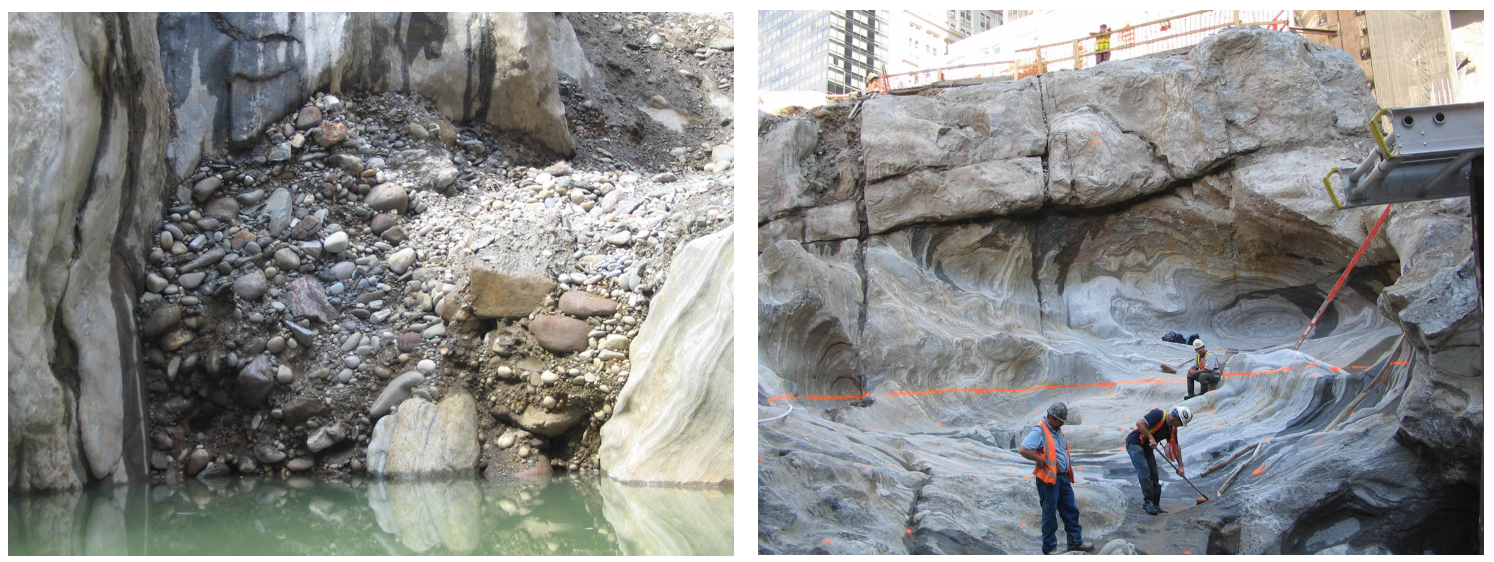

Figure 10 - The bedrock at the World Trade Center site was scoured into deep plunge pools and potholes, especially around the contact zone between schistose rock and large masses of hard granite pegmatite. The plunge pools were then filled with a dense boulder and cobbly till. On the left, the till is still filling the west side of the western plunge pool. On the right, the till has been removed from the east side of the same plunge pool for construction. It is likely that at least the lowest tier of the Manhattanville valley resembles this combination of scoured rock filled with till. (From Moss \& Merguerian 2009) 
The deepest part of the valley was scoured out prior to and/or during the Wisconsinan Last Glacial Maximum (Figure 9). That advance plastered the lowest tier with basal till. When the ice initially retreated from the neighborhood the valley bottom filled up to the outlets with varved sediments and a little fine-grained outwash. It is not known if this was a local isolated pro-glacial pool or if it connected to other features through the western outlet to the Hudson River and/or the eastern outlet to the Harlem/East River. If any sediments were deposited higher than the level of the outlets, they were eroded during one of the many local glacial readvances that took place during recession from the Last Glacial Maximum.

The first readvance identified over the site covered the previous strata with a blanket of outwash sand and sent a small lobe of ice eastward into the valley, before the retreating ice front fluctuated across the site leaving behind interlayered strata dominated by meltwater deposition. In some places even the till was a bit cleaner than a typical basal till. When the ice retreated the varved sediments likely entered the valley from the Hudson, before moving over the site.

The next readvance of the ice planed off the previous deposits roughly level with the top of rock along the sides of the valley. Denser soil below this level indicates the ice covered the site even though the thickest till lies in two bands along the upper edges of the valley, forming a basin. With final retreat of the ice, glacial lake deposits filled in the till depression starting from the Hudson, before eventually covering most of the site. Further research is needed to determine which event or combination of events led to a subsequent drop in the groundwater table that allowed the surface of this upper varved stratum to become desiccated.

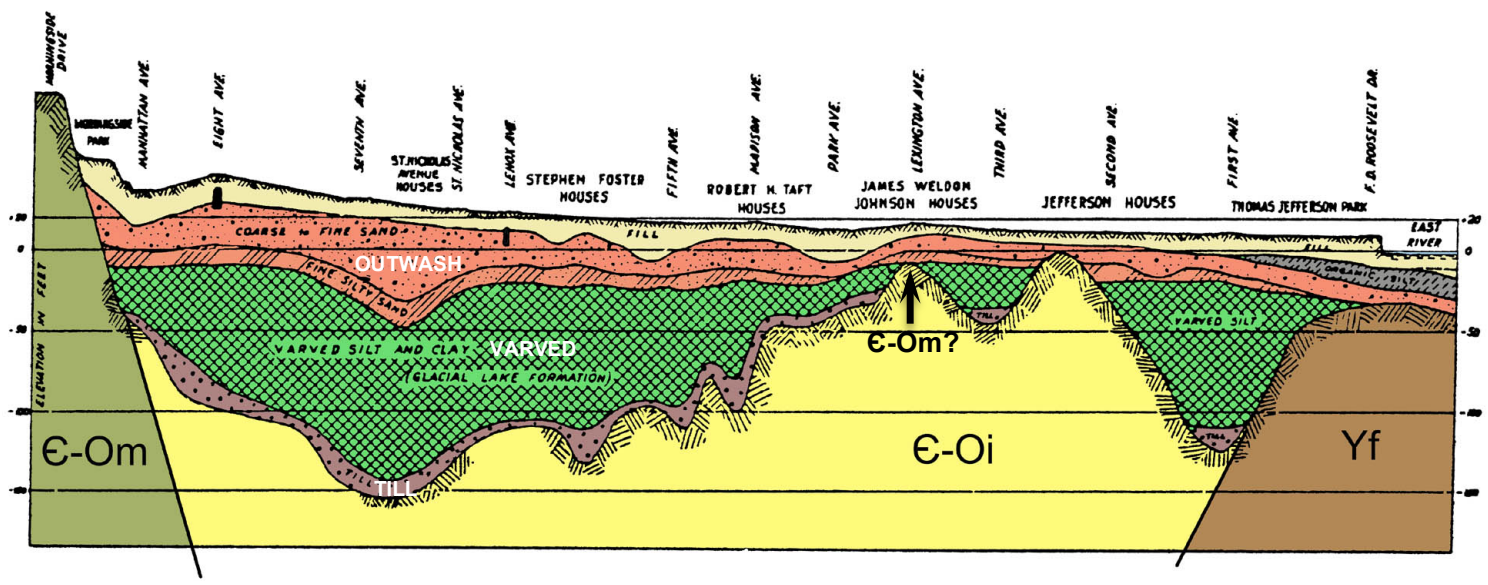

Figure 11 - Geologic cross-section along $113^{\text {th }}$ Street east of Morningside Drive. This is one of many places in the city where the Inwood Marble was eroded into a deep valley and filled with glacial sediments, including thick layers of varved glacial lake strata. These lakes aren't shown on published geologic maps, and since they may not all be local isolated features their presence should be considered when interpreting New York City's glacial history. (Updated from Moss \& Merguerian 2005, the annotated, colorized version adapted from Parsons 1976.). 
The Stanford map (Figure 7) places Lake Bayonne south of the Manhattanville neighborhood, and Lake Hudson at the western edge of the site. If this is correct, then the Manhattanville varved sediments are either local deposits or were linked to glacial Lake Hudson. Of interest, the map does not show any glacial lakes over northern Manhattan east of the Hudson or west of the Harlem River. Data in the MRCE archives indicates that borings made in this area, especially in places where the Inwood Marble was eroded into valleys, show that glacial lake deposits are present, in some places to great depth (Figure 11). Some of these locations may have isolated local deposits, but some may connect to larger lakes present in the East River/Harlem River vicinity. It is also possible that some of the features present in Manhattanville link through the valley's eastern outlet to comparable features such as shifting ice fronts or lakes present in East Harlem.

\section{Acknowledgements}

I would like to thank Larisa Reva of Mueser Rutledge Consulting Engineers for her assistance in drafting some of the figures. I would like to thank Jan Cermak of Mueser Rutledge Consulting Engineers for his assistance in obtaining client permission to publish. I also want to thank Columbia University and their Manhattanville Development Office for allowing me to publish information obtained from their project.

\section{References}

Baskerville, C.A., 1992, Bedrock and engineering geologic maps of Bronx County and parts of New York and Queens Counties, New York: U.S. Geological Survey, Miscellaneous Investigations Series Map I2003, scale 1:24000.

Baskerville, C.A., 1994, Bedrock and engineering geologic maps of New York County and parts of Kings and Queens Counties, New York, and parts of Bergen and Hudson Counties, New Jersey: U.S. Geological Survey, Miscellaneous Investigations Series Map I-2306, scale 1:24000.

Flint, R. F.; and Gebert, J. A., 1974, End moraines on and off the Connecticut shore (abstract): Geological Society of America, Abstracts with Programs, v. 6, no. 7, p. 738-739.

Moss, C. J., and Merguerian, Charles, 2005, Loading patterns in varved Pleistocene sediment in the NYC area: in Hanson, G. N., chm., Twelfth Annual Conference on Geology of Long Island and Metropolitan New York, 16 April 2005, State University of New York at Stony Brook, NY, Long Island Geologists Program with Abstracts, $12 \mathrm{p}$.

Moss, Cheryl J., and Merguerian, Charles, 2009, 50 Ka Till-Filled Pleistocene Plunge Pools and Potholes Found Beneath the World Trade Center Site, New York, NY: in Hanson, G. N., chm., Sixteenth Annual Conference on Geology of Long Island and Metropolitan New York, 28 March 2009, State University of New York at Stony Brook, NY, Long Island Geologists Program with Abstracts, 19 p.

Moss, Cheryl J., 2009, Boulder till filled plunge pools found at the World Trade Center site, NYC, NY, Geological Society of America Abstracts with Programs, v. 41, no. 3, p. 35. GSA-Northeastern Section 44th Annual Meeting in Portland, ME (22-24 March 2009)

Moss, Cheryl J., 2011a, Geotechnical Evidence of Multiple Glacial Advances in New York City's Subsurface, Geological Society of America Abstracts with Programs, v. 43, no. 1, p. 95. 
Moss, Cheryl J., 2011b, Use of Engineering Properties to Identify Multiple Glacial Advances in New York City's Subsurface: in Hanson, G. N., Chm., 18th Annual Conference on Geology of Long Island and Metropolitan New York, 9 April 2011, State University of New York at Stony Brook, NY, Long Island Geologists Program with abstracts, $13 \mathrm{p}$.

Moss, Cheryl J., 2012a, Evidence of two Wisconsin age glacial advances in a valley beneath the new Yankee Stadium, Bronx, New York, Geological Society of America Abstracts with Programs, v. 44, no. 2, p. 71. GSA-Northeastern Section - 47th Annual Meeting in Hartford, CT (18-20 March 2012)

Moss, Cheryl J., 2012b, Evidence of Two Wisconsin Age Glacial Advances in a Bedrock Valley Below the New Yankee Stadium, Bronx, New York: in Hanson, G. N., Chm., 19th Annual Conference on Geology of Long Island and Metropolitan New York, 14 April 2012, State University of New York at Stony Brook, NY, Long Island Geologists Program with abstracts, 13 p.

Moss, Cheryl J., 2013a, Evidence from the Citifield Stadium site, Queens, New York City, NY of glacial readvances during recession from the Last Glacial Maximum, Geological Society of America Abstracts with Programs, v. 45, no. 1, p. 106. GSA-Northeastern Section - 48th Annual Meeting in Bretton Woods, NH (18-20 March 2013)

Moss, Cheryl J., 2013b, Evidence of glacial readvances during recession from the Last Glacial Maximum from the Citifield Stadium site, Queens, New York City, NY: in Hanson, G. N., Chm., 20th Annual Conference on Geology of Long Island and Metropolitan New York, 13 April 2013, State University of New York at Stony Brook, NY, Long Island Geologists Program with abstracts, 11 p.

Moss, Cheryl J., 2014a, Steady then stagnant - Aspects of LGM deglaciation in Flushing Meadows, Queens, New York, Geological Society of America Abstracts with Programs, v. 46, no. 2, p. 45. GSANortheastern Section - 49th Annual Meeting in Lancaster, PA (23-25 March 2014)

Moss, Cheryl J., 2014b, Aspects of LGM deglaciation in Flushing Meadows, Queens, New York City, NY: in Hanson, G. N., Chm., 21th Annual Conference on Geology of Long Island and Metropolitan New York, 12 April 2014, State University of New York at Stony Brook, NY, Long Island Geologists Program with abstracts, $13 \mathrm{p}$.

Moss, Cheryl J., 2016a, Stratigraphy Across the Hudson River as Revealed in Borings for the New NY Bridge Replacing the Tappan Zee, Tarrytown - Nyack, Geological Society of America Abstracts with Programs, v. 48, no. 2. GSA-Northeastern Section - 51st Annual Meeting in Albany, NY (21-23 March 2016)

Moss, Cheryl J., 2016b, Stratigraphy Across the Hudson River, Tarrytown - Nyack, NY Updated From Borings for the New NY Bridge Replacing the Tappan Zee: in Hanson, G. N., Chm., 23th Annual Conference on Geology of Long Island and Metropolitan New York, 16 April 2016, State University of New York at Stony Brook, NY, Long Island Geologists Program with abstracts, 13 p.

Nikolaou, Sissy, 2004, Local Geology of New York City and its Effect on Seismic Ground Motions, in Proceedings: Fifth International Conference on Case Histories in Geotechnical Engineering, New York, NY, April 13-17, 2004, 14 p.

Parsons, J. D., 1976, New York's glacial lake formation of varved silt and clay: Proceedings of the American Society of Civil Engineers, Journal of Geotechnical Engineering Division, vol. 102, no. GT6, p. 605-638.

Sanders, John E.; and Merguerian, Charles, 1994, Glacial geology of the New York City region, p. 93-200 in Benimoff, A. I., ed., The geology of Staten Island, New York: Geological Association of New Jersey Annual Meeting, 11th, Somerset, NJ, 14-15 October 1994, Field guide and proceedings, 296 p.

Sanders, John E.; and Merguerian, Charles, 1998, Classification of Pleistocene deposits, New York City 
and vicinity - Fuller (1914) revived and revised: p. 130-143 in Hanson, G. N., chm., Geology of Long Island and metropolitan New York, 18 April 1998, State University of New York at Stony Brook, NY, Long Island Geologists Program with Abstracts, $161 \mathrm{p}$.

Stanford, S. D., and Harper, D. P, 1991, Glacial lakes of the lower Passaic, Hackensack, and lower Hudson valleys, New Jersey and New York, Northeastern Geology, vol. 13, no. 4, p. 271-286.

Stanford, Scott D., 2010a, Onshore record of Hudson River drainage to the continental shelf from the late Miocene through the late Wisconsinan deglaciation, USA: synthesis and revision, Boreas, vol. 39, p 1-17.

Stanford, Scott D., 2010b, Glacial Geology and Geomorphology of the Passaic, Hackensack, and Lower Hudson Valleys, New Jersey and New York, p. 47-84 in Benimoff, A. I., ed., New York State Geological Association $82^{\text {nd }}$ Annual Meeting Field Trip Guidebook, Staten Island, NY, 24-26 September 2010, 190 p.

\section{Moss, Cheryl J., 2018b, Interpreting the Stratigraphic Record of Glacial Readvances Along the Hudson River at Manhattanville, New York City, NY: in Hanson, G. N., Chm., 25th Annual Conference on Geology of Long Island and Metropolitan New York, 14 April 2018, State University of New York at Stony Brook, NY, Long Island Geologists Program with abstracts, 13 p.}

